\title{
Perbaikan Efektivitas Pekerja Menggunakan Overall Labour Effectiveness dan Fault Tree Analysis Studi Kasus: PT. Riau Graindo Dumai
}

\author{
Anwardi ${ }^{1}$, Yoga Pratama ${ }^{2}$ \\ 1,2 Jurusan Teknik Industri, Fakultas Sains dan Teknologi, UIN Sultan Syarif Kasim Riau \\ Jl. HR. Soebrantas No. 155 Simpang Baru, Panam, Pekanbaru, 28293 \\ Email :
}

\begin{abstract}
ABSTRAK
Tingginya produk cacat di PT. Riau Graindo yang disebabkan oleh efektivitas pekerja yang kurang memberikan kontribusi yang efektif membuat penjualan koran menjadi berkurang yang berdampak kepada profit perusahaan. Langkah-langkah untuk memperbaiki efektivitas pekerja yaitu dengan menggunakan metode Overall Labour Effectiveness (OLE) dan Fault Tree Analysis (FTA). Tujuan penelitian ini yaitu mengetahui nilai OLE perusahaan, mendapatkan kegagalan yang menyebabkan produk cacat, memberikan usulan dan mengiplementasi usulan tersebut. Hasil yang didapatkan dari penelitian ini yaitu usulan yang diberikan yaitu memberikan lembar contoh dengan ukuran A3 yang disesuaikan untuk setiap koran yang berwarna dimana nilai OLE perusahaan bulan Januari-Desember 2016 adalah 63,92\%. Hasil implementasi mampu meningkatkan nilai OLE perusahaan sebesar 4,8\% menjadi $68,72 \%$. Kenaikan terdapat pada jumlah produksi dimana rata-rata perbulan 117.859 eksemplar naik menjadi 121.456 eksemplar. Selain itu juga jumlah produk cacat turun dari 4360 eksemplar menjadi 3924 eksemplar yang memberikan pengaruh terhadap penambahan income perusahaan sebesar Rp 1.308.000 pada bulan Juli 2017.
\end{abstract}

Kata Kunci: Efektivitas Pekerja, Fault Tree Analysis (FTA), Overall Labour Effectiveness (OLE)

\section{Pendahuluan}

PT. Riau Graindo Dumai merupakan salah satu pabrik percetakan koran yang berada di Kota Dumai, Provinsi Riau. Produk yang dihasilkan berupa koran dan majalah. PT. Riau Graindo merupakan salah satu badan usaha milik swasta yang bergerak dibidang percetakan. Pada 17 Januari 1997. PT. Riau Graindo Dumai memiliki 8 orang karyawan yang bekerja dibagian produksi dengan waktu kerja selama 8 jam yang dimulai pukul $20.00 \mathrm{WIB}$ atau 21.00 WIB. Adapun hasil produksi pada tahun 2016 sebagaimana gambar 1 berikut.

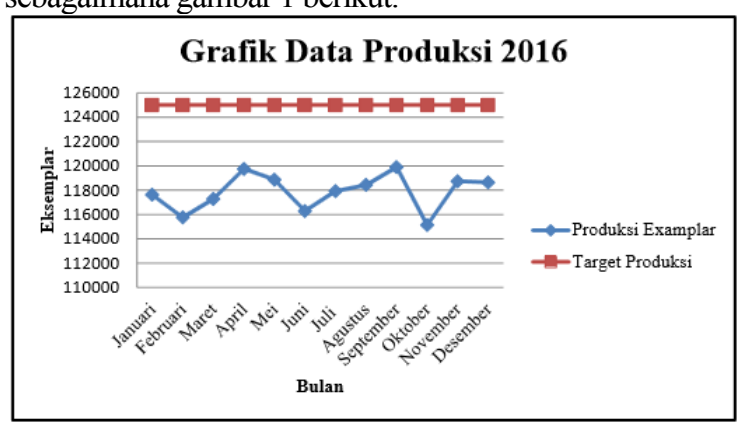

Gambar 1. Grafik data produksi 2016

Berdasarkan grafik diatas, bahwa PT. Riau Graindo Dumai masih mengalami kesulitan dalam mencapai target yang telah ditetapkan, dimana terlihat bahwa jumlah produksi tertinggi pada bulan September sebesar 119.898 examplar dan belum memenuhi target produksi yaitu 125.000 eksemplar per bulan. Target produksi tidak dapat terpenuhi disebabkan oleh tingginya produk yang cacat. Oleh sebab itu diperlukan untuk mengukur tingkat efektivitas perusahaan dengan menggunakan Overall Labour Effectiveness. Penggunaan metode Overall Labour Effectiveness dikarenakan variabel yang akan dianalisis meliputi bagaimana kualitas pekerja dan pemanfaatan efektivitas pekerja oleh perusahaan. tersebut sehingga dipilih metode ini untuk analisis terhadap efetivitas tenaga kerja. Perhitungan yang akan dilakukan yaitu untuk mengetahui efektivitas tenaga kerja keseluruhan (OLE). Setelah OLE perusahaan diketahui, maka selanjutnya dilakukan analisis akar penyebab masalah dan solusinya dengan menggunakan Fault Tree Analysis (FTA). Pencarian akar penyebab masalah difokuskan kepada ketersediaan kinerja pekerja terhadap kualitas produk sehingga menyebabkan kehilangan output karena cacat.

\section{Tinjauan Pustaka}

\section{Efektivitas}

Efektivitas adalah informasi harus sesuai dengan kebutuhan pemakai dalam mendukung suatu proses bisnis, termasuk didalam informasi tersebut harus disajikan dalam waktu yang tepat, format yang tepat 
sehingga dapat dipahami, konsisten dengan format sebelumnya, isinya sesuai dengan kebutuhan saat ini dan lengkap atau sesuai dengan kebutuhan saat ini dan lengkap atau sesuai dengan kebutuhan dan ketentuan (Susanto, 2007 dikutip oleh Herlyna, 2014).

\section{Overall Labour Effectiveness (OLE)}

Efektivitas Keseluruhan Pekerja (Overall Labour Effectiveness) digunakan untuk mengukur efektivitas, pemanfaatan kinerja dan kualitas pekerja yang berpengaruh terhadap hasil produksi atau produktivitasnya di lantai pabrik dan profitabilitas melalui pengukuran konstribusi dari pekerja. Adapun tiga faktor yang akan diukur dalam OLE yaitu ketersediaan (Availability), yaitu persentase waktu yang dihabiskan pekerja dalam memberikan konstribusi efektif, Kinerja (Performance) yaitu jumlah produk yang diserahkan serta Kualitas (Quality) yaitu persentase produk tanpa cacat (sempurna yang diproduksi atau dapat dijual). OLE memberikan kepada manajemen kemampuan untuk menganalisis pengaruh kumulatif dari ketiga faktor pekerja (Availability, Performance, Quality) pada output yang dihasilkan. Analisis lebih lanjut untuk mencari akar penyebab masalah menemukan penyebab utama yang mempengaruhi nilai OLE.

\section{Fault Tree Analysis (FTA)}

Analisis lebih lanjut untuk mencari akar penyebab yang akan dilakukan yaitu dengan menggunakan metode Fault Tree Analysis (FTA). FTA merupakan suatu alat analisis yang membuat gabungan dari kegagalan yang pasti terhadap suatu sistem. FTA ini berguna untuk menggambarkan kejadian dalam suatu sistem. Kelebihan dari FTA adalah dapat menganalisa kegagalan sistem, dapat mencari aspek-aspek dari sistem yang terlibat dalam kegagalan utama dan menemukan penyebab terjadinya kecacatan produk pada proses produksi. FTA adalah satu diagram satu arah dan menghubungkan informasi yang dikembangkan dalam analisa cara kegagalan dan akibatnya (Setyadi, 2013).

\section{Metode Penelitian}

Penelitian ini dilakukan di PT. Riau Graindo Dumai yang bergerak di bidang percetakan Koran dan Majalah. Penelitian dilakukan dengan menggunakan perhitungan OLE dan analisis FTA untuk melakukan perbaikan. Hasil akhir penelitian ini berupa penerapan usulan perbaikan yang diterapkan pada PT. Riau Graindo Dumai.

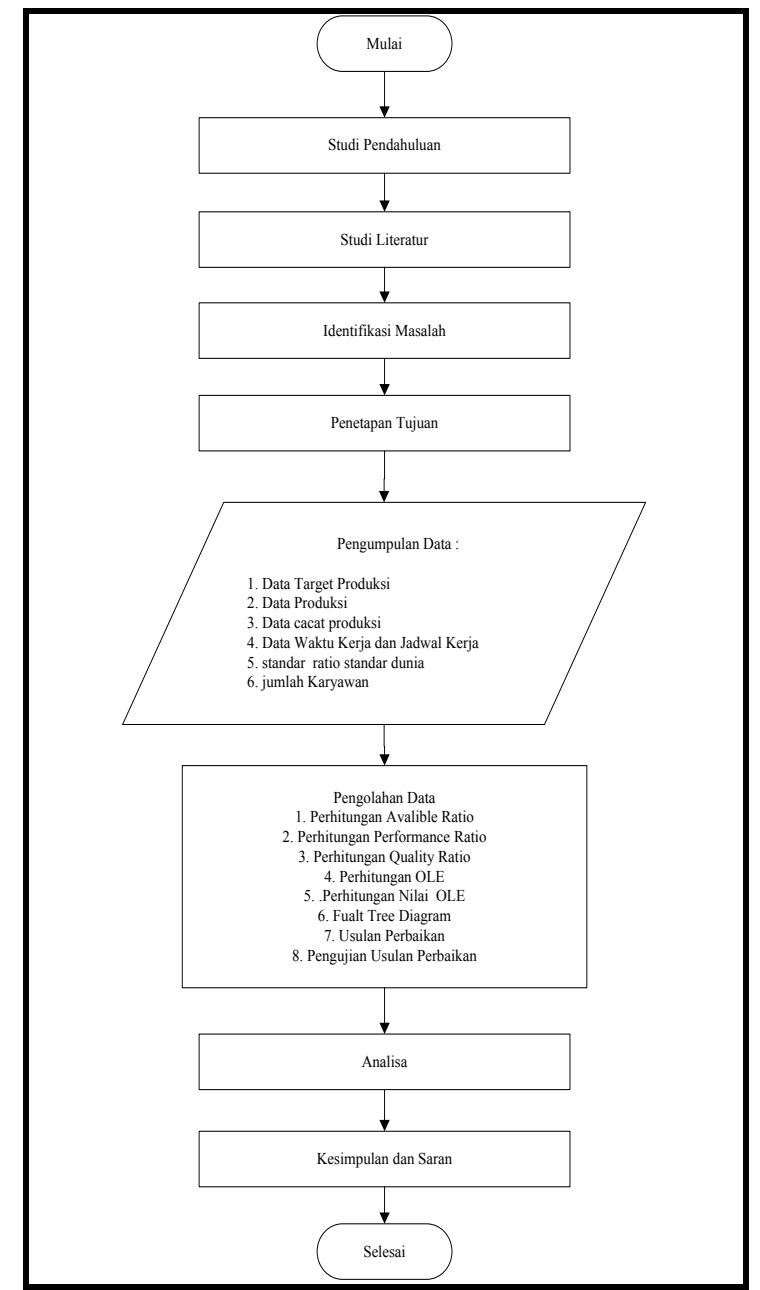

Gambar 1. Flowchart alur penelitian

Proses pengolahan data dilakukan dengan perhitungan nilai OLE untuk melihat efektifitas pekerja. Selanjutnya analisis lebih lanjut menggunakan Fault Tree Analysis.

Availability Ratio (Mengukur Keterediaan) Menghitung penggunaan waktu kerja dari penggunaan waktu yang tersedia untuk kegiatan produksi. Waktu yang diukur dari waktu bekerja produktif dibagi dengan waktu yang disediakan perusahaan.

$\mathrm{R}=\frac{\text { Waktu Bekerja Produktif }- \text { Downtime }}{\text { Waktu Terjadwal }} \times 100 \%$

Performance Ratio (Mengukur Kinerja) digunakan untuk mengukur kinerja pekerja dengan cara menentukan aktual output yang dihasilkan pekerja dibagi dengan output yang ditetapkan perusahaan.

Performance Ratio $=\frac{\text { Aktual Output }}{\text { Target Produksi }} \times 100 \%$

Quality Ratio Menghitung kemampuan pekerja dalam menghasilkan produk yang sesuai standar. Ini 
difokuskan pada kerugian dari banyaknya kerusakan yang terjadi pada produk.

QualityRatio $=\frac{\text { Target Produksi-Jumlah Cacat }}{\text { Jumlah Produks }} \times 100 \%$

Perhitungan Overall Labour Effectiveness (OLE) merupakan nilai yang dihasilkan dari perkalian tiga ratio. Nilai yang diketahui tersebut dibandingkan dengan nilai OLE standar.

\section{OLE $=$ Availability $x$ Performance $x$ Quality}

Fault Tree Analysis (FTA) Analisa akar masalah adalah sebuah alat kerja yang sangat berguna untuk mencari akar masalah dari suatu insiden yang telah terjadi.. FTA adalah salah satu teknik yang dapat diandalkan, dimana kegagalan yang tidak diinginkan, diatur dengan cara menarik kesimpulan dan dipaparkan dengan gambar.

Usulan Pemecahan Masalah Usulan diharapkan dapat memperbaiki efektivitas pekerja secara keseluruhan pada lantai produksi. Menurut penelitian Rosi Rosa Lina tahun 2015, usulan yang diberikan jika kegagalan yang terjadi pada manusia adalah memberikan program latihan, penerapan sanksi kepada karyawan, rancangan kerja berupa menetapkan tugas secara terstruktur, perencanaan tenaga kerja (Lina, 2015). Menurut penelitian Trisnal tahun 2013, usulan yang diberikan jika kegagalan terjadi pada mesin produksi dan lantai produksi yaitu membuat standard operating procedure, sosialisasi berupa visual control atau display dan membuat prosedur pada proses inspeksi (Trisnal, 2013).

Pengujian Usulan Perbaikan Tahap selanjutnya adalah menguji hasil perancangan usulan yang dilakukan pada lantai produksi di PT. Riau Graindo Dumai . Pada tahap

pengujian, usulan yang sudah dirancang kemudian diterapkan ke tempat penelitian untuk di uji, hal ini bertujuan untuk melihat perubahan efektivitas pekerja. Adapun uji yang akan dilakukan yaitu pengukuran nilai Overall Labour Effetiveness.

\section{Hasil dan Pembahasan}

\section{Perhitungan Nilai Avaibility Ratio}

Untuk mengukur Availability Ratio pada saat proses pengolahan koran pada bulan yang tidak mencapai target perusahaan adalah sebagai berikut:

\section{Januari Availability Ratio}

$\mathrm{R}=\frac{\text { Waktu Bekerja Produktif }- \text { Downtime }}{\text { Waktu Terjadwal }} \times 100 \%$

$$
=\frac{132-24}{156} \times 100 \%
$$

$=69,23 \%$
Tabel 1. Rekapitulasi perhitungan availability ratio proses koran

\begin{tabular}{|c|l|c|}
\hline No & \multicolumn{1}{|c|}{ Bulan } & Available Ratio \\
\hline 1 & Januari & 69,23 \\
\hline 2 & Februari & 70,67 \\
\hline 3 & Maret & 74,07 \\
\hline 4 & April & 73,33 \\
\hline 5 & Mei & 70,37 \\
\hline 6 & Juni & 65,38 \\
\hline 7 & Juli & 69,23 \\
\hline 8 & Agustus & 71,79 \\
\hline 9 & September & 73,08 \\
\hline 10 & Oktober & 66,67 \\
\hline 11 & November & 69,14 \\
\hline 12 & Desember & 71,60 \\
\hline
\end{tabular}

\section{Perhitungan Nilai Performance Ratio}

Untuk mengukur Performance Ratio pada saat proses pengolahan koran pada bulan yang tidak mencapai target perusahaan adalah sebagai berikut:

1. Januari

$$
\begin{aligned}
\text { Performance Ratio } & =\frac{\text { Aktual Output }}{\text { Target Produksi }} \times 100 \% \\
& =\frac{117.624}{125.000} \times 100 \% \\
& =94,10 \%
\end{aligned}
$$

Untuk perhitungan bulan selanjutnya dapat dilihat pada rekapitulasi perhitungan performance ratio. Adapun rekapitulasi hasil perhitungan adalah ditunjukkan pada tabel 2 berikut.

Tabel 2. Rekapitulasi perhitungan performance ratio pada proses koran

\begin{tabular}{|c|l|c|}
\hline No & \multicolumn{1}{|c|}{ Bulan } & Available Ratio \\
\hline 1 & Januari & 94,1 \\
\hline 2 & Februari & 92,6 \\
\hline 3 & Maret & 93,83 \\
\hline 4 & April & 95,8 \\
\hline 5 & Mei & 95,09 \\
\hline 6 & Juni & 93,03 \\
\hline 7 & Juli & 94,34 \\
\hline 8 & Agustus & 94,74 \\
\hline 9 & September & 95,92 \\
\hline 10 & Oktober & 92,11 \\
\hline 11 & November & 94,99 \\
\hline 12 & Desember & 94,91 \\
\hline
\end{tabular}




\section{Perhitungan Nilai Quality Ratio}

1. Januari

Quality Ratio $=\frac{\text { Target Produksi-Jumlah Cacat }}{\text { Jumlah Produks }} \times 100 \%$

$$
\begin{aligned}
& =\frac{117624-4352}{117624} \times 100 \% \\
& =96,30 \%
\end{aligned}
$$

Berikut adalah rekapitulasi perhitungan quality ratio pada proses pengolahan Koran.

Tabel 3. Perhitungan quality ratio pada proses koran

\begin{tabular}{|c|l|c|}
\hline No & \multicolumn{1}{|c|}{ Bulan } & Available Ratio \\
\hline 1 & Januari & 96,3 \\
\hline 2 & Februari & 96,5 \\
\hline 3 & Maret & 96,3 \\
\hline 4 & April & 96,1 \\
\hline 5 & Mei & 96,2 \\
\hline 6 & Juni & 96,4 \\
\hline 7 & Juli & 96,3 \\
\hline 8 & Agustus & 96,2 \\
\hline 9 & September & 96,1 \\
\hline 10 & Oktober & 96,5 \\
\hline 11 & November & 96,2 \\
\hline 12 & Desember & 96,5 \\
\hline
\end{tabular}

\section{Perhitungan Nilai Overall Labour Effectiveness (OLE)}

Perhitungan nilai Overall Labour Effectiveness (OLE) didapat dari perkalian tiga rasio, yaitu.

1. Januari

OLE $=($ Availability Ratio $\times$ Performance Ratio $\times$ Quality Ratio)

$=(69,23 \%$ x $94,10 \% \times 96,30 \%)$

$$
=62,74 \%
$$

Berikut adalah rekapitulasi hasil perhitungan OLE pada proses pengolahan Koran:

Tabel 4. Rekapitulasi OLE pada Proses Koran

\begin{tabular}{|c|l|c|}
\hline No & \multicolumn{1}{|c|}{ Bulan } & OLE (\%) \\
\hline 1 & Januari & 62,74 \\
\hline 2 & Februari & 63,15 \\
\hline 3 & Maret & 66,93 \\
\hline 4 & April & 67,51 \\
\hline 5 & Mei & 64,37 \\
\hline 6 & Juni & 58,63 \\
\hline 7 & Juli & 62,9 \\
\hline 8 & Agustus & 65,43 \\
\hline 9 & September & 67,36 \\
\hline 10 & Oktober & 59,26 \\
\hline 11 & November & 63,18 \\
\hline 12 & Desember & 65,58 \\
\hline
\end{tabular}

Berdasarkan tabel 4,bahwa perhitungan ke tiga rasio setiap bulannya dengan nilai rata-rata $63.92 \%$ yang berarti bahwa kondisi OLE masih berada di bawah standar dunia (95\%). Untuk mencapai atau mendekati standar tersebut, maka akan dilakukan perbaikan dengan cara menggunakan pendekatan Foult Tree Analysis (FTA).

Untuk mencari akar permasalah dilakukan dengan menggunakan pendekatan Fault Tree Analysis (FTA). Adapun permasalahan yang terjadi yaitu nilai OLE perusahan yang rendah yaitu 63,92\% dimana menurut (Saragaon, 2012 dikutip oleh Lina, 2015), bahwa nilai OLE standar internasional yaitu 95\%. Oleh sebab itu maka diperlukan analisis terhadap kegagalan yang menyebabkan nilai OLE perusahaan rendah dengan menggunakan Fault Tree Analysis (FTA). Berikut gambar kegagalan-kegagalan yang menyebabkan nilsi OLE perusahaan rendah:

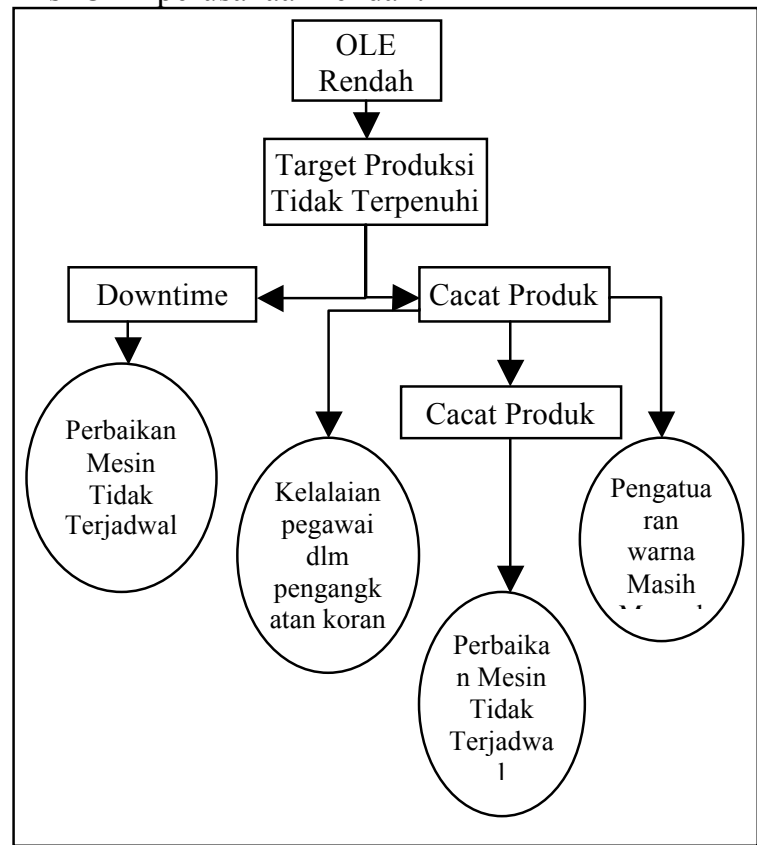

Gambar 2. Fault tree analysis terhadap nilai oleh perusahaan

Dari Fault Tree Analysis tersebut didapat kegagalan-kegagalan dasar yang menyebabkan nilai OLE perusahaan dibawah standar internasional:

1. Perbaikan mesin tidak terjadwal.

2. Pegawai lalai saat pengangkatan koran.

3. Pegawai tidak disiplin setelah melakukan pengisian ulang tinta.

4. Pengaturan warna secara manual.

\section{Usulan Perbaikan Manajemen Kerja}

Usulan terhadap perbaikan manajemen kerja pada lantai produksi ditujukan terhadap kegagalankegagalan dasar yang menyebabkan nilai OLE perusahan sehingga perlu diberikan solusi penyelesaiaannya sebagai berikut: 
1. Membuat perencanaan terhadap perbaikan mesin dan mengganti komponen-komponen kritis sehingga dapat menghindarkan downtime pada mesin. Selain itu juga menambahkan pemeriksaan pada mesin oleh teknisi minimal 1 jam sebelum dilakukannya proses produksi.

2. Manajer produksi memberikan pengarahan dalam pengangkatan koran dan membuat peringatan kepada pegawai untuk tidak lalai dan sembarangan dalam pengangkat koran yang dilakukan.

3. Memberikan pengarahan dalam melakukan pengisian ulang tinta, dimana ember tinta yang telah selesai digunakan harus diletakkan kembali ke tempat penyimpanan tinta agar tinta yang tersisa tidak tercecer di area pengangkutan.

4. Penerapan sanksi yang lebih tegas kepada pekerja yang tidak disiplin, sanksi-sanksi tersebut dapat berupa pengurangan gaji, peringatan tertulis, peringatan tertulis pertama, kedua dan ketiga, kemudian sanksi-sanksi lainnya, pekerja dapat diberhentikan sementara.

5. Membuat lembar contoh koran dengan ukuran A3 yang disesuaikan untuk setiap koran berwarna yang akan dicetak sehingga pegawai dapat mengetahui perpaduan warna pada koran saat pertama mencetak karena pengaturan yang dilakukan pada mesin web warna masih manual oleh operator. Lembar contoh ini menjadi acuan operator dalam memproduksi koran.

Usulan yang akan diterapkan yaitu pada poin 5 dimana usulan tersebut diharapkan dapat mengurangi tingkat kecacatan produk yang terjadi pada proses penyetalan warna.

\section{Evaluasi Usulan Perbaikan Manajemen Kerja}

Setelah dilakukan tahap implementasi atas usulan yang diberikan selama satu bulan yaitu pada bulan Juli 2017, maka selanjutnya evaluasi terhadap usulan yang diberikan. Berikut adalah data produksi dan data jam kerja karyawan pada bulan Juli 2017:

1. Produksi : 121.456 Eksemplar

2. Reject : 3924 Eksemplar

3. Target Produksi : 125.000 Eksemplar

4. Total Waktu Terjadwal : 156 jam

5. Total Waktu Produktif : 135 jam

6. Total Waktu Tidak Produktif: $21 \mathrm{jam}$

Perhitungan yang akan dilakukan yaitu menghitung Avaibility Ratio, Performance Ratio, Quality Ratio, Nilai OLE PT. Riau Graindo Dumai pada bulan Juli 2017. Berikut adalah perhitungannya:

$\mathrm{R}=\frac{\text { Waktu Bekerja Produktif }- \text { Downtime }}{\text { Waktu Terjadwal }} \times 100 \%$

$$
\begin{aligned}
& =\frac{135-21}{156} \times 100 \% \\
& =73,08 \% \\
& \text { Performance Ratio }=\frac{\text { Aktual Output }}{\text { Target Produksi }} \times 100 \% \\
& =\frac{117.121 .456 .624}{125.000} \times 100 \% \\
& =97,17 \% \\
& \text { Quality Ratio }=\frac{\text { Target Produksi-Jumlah Cacat }}{\text { Jumlah Produks }} \times 100 \% \\
& =\frac{121.456-3.914}{121.456} \times 100 \% \\
& =96,77 \%
\end{aligned}
$$

Sehingga nilai OLE yang diperoleh:

OLE = (Availability Ratio $\times$ Performance Ratio $\times$ Quality Ratio)

$=(73,08 \% \times 97,17 \% \times 96,77 \%)$

$=68,72 \%$

Hasil evaluasi selama satu bulan yaitu pada bulan Juli 2017 menunjukkan peningkatan pada nilai OLE perusahaan. Berdasarkan perhitungan yang dilakukan pada bulan Juli 2017 yaitu 68,72\%. Nilai tersebut meningkat yang sebelumnya $63,92 \%$ dengan selisih 4,8\%. Kenaikan terdapat pada jumlah produksi dimana rata-rata perbulan 117.859 eksemplar naik menjadi 121.456 eksemplar. Selain itu juga jumlah produk cacat turun dari rata-rata perbulan 4360 eksemplar menjadi 3924 eksemplar. Turunnya produk cacat juga menambah income perusahaan sebesar Rp 1.308 .000 pada bulan Juli 2017. Namun nilai tersebut belum mencapai nilai standar internasional yaitu 95\%. Penigkatan nilai terdapat pada nilai ketiga rasio, namun Performance Ratio menjadi peningkatan tertinggi yaitu $2,88 \%$. Peningkatan ini didapat dari nilai jumlah produksi meningkat pada bulan Juli 2017. Meningkatnya jumlah produksi dikarenakan jumlah produk cacat yang dihasilkan pada bulan Juli 2017 mengalami penurunan.

Berdasarkan hal tersebut dapat dinyatakan bahwa usulan yang diberikan mampu meningkatkan jumlah prodksi dan menurunkan jumlah produk cacat. Perbaikan yang dilakukan hanya pada satu elemen saja. Apabila semua usulan yang diberikan diterapkan, maka tidak menutup kemungkinan dapat meningkatkan nilai OLE perusashaan sebesar 20\% dimana anggapan untuk setiap usulannya mampu meningkatkan nilai OLE sebesar 4\%. Organisasi yang efektiv ditentukan oleh individu yang efektiv 
dan beberapa faktor yang mempengaruhi efektivitas individu (Gibson, 1987 dikutib oleh Nasution, 2015)

\section{Kesimpulan}

Hasil pengukuran efektivitas pekerja menggunakan metode Overall Labour Effectiveness (OLE) pada PT. Riau Graindo Dumai diperoleh $63,92 \%$, sedangkan kegagaan-kegagalan dasar yang menyebabkan nilai OLE perusahaan dibawah standar internasional berdasarkan pendekatan Fault Tree Analysis antara lain tidak adanya jadwal perbaiakn mesin secara berkala, adanya kelalaian pekerja dalam melakukan aktivitasnya, tingkat kedisiplinan pegawai yang kurang, terutama saat pengisian ulang tinta. pengaturan warna masih dilakukan secara manual.

Untuk meningkatkan nilai OLE, salah satu usulan yang diterapkan yaitu dengan membuat lembar contoh koran dengan ukuran A3 yang disesuaikan untuk setiap koran berwarna yang akan dicetak sehingga pegawai dapat mengetahui perpaduan warna koran pada saat pertama mencetak yang saat ini masih dilakukan pada mesin web warna secara manual. Lembar contoh ini menjadi acuan operator dalam memproduksi Koran dan mampu meningkatkan nilai OLE sebesar $4.8 \%$.

\section{Daftar Pustaka}

[1] Anshori, N, Mustajib, I. M. "Sistem Perawatan Terpadu (Intregrated Maintenance System)". Yogyakarta: Graha Ilmu, 2013.

[2] Gazpers, V. "Integrated Total Quality Talent Management". Tri Al Bros Publishing. Jakarta: Gramedia Pustaka Utama. 2013.

[3] Herlyna, 2014 "Studi Tentang Efektivitas Kerja Pegawai Di Badan Kepegawaian Daerah

[4] Nasution, A. M. Pengaruh Komunikasi Organisasi Terhadap Tingkat Produktivitas Kerja Karyawan Di PT. Panen Lestari Internusa Sogo Medan. Jurnal Implementasi Eknonomi dan Bisnis. id.portalgaruda.org, 2015.

[5] Setyadi, I. “Analisis Penyebab Kecacatan Produk Celana Jeans Dengan Menggunakan Metode Fault Tree Analysis (FTA) Dan Failure Mode And Effect Analysis (FMEA) Di Cv Fragile Din Co". repository.widyatama.ac.id, 2013. 